${ }^{\circledR}$ Entomologica Fennica. 5 December 1995

\title{
Carabid beetle assemblages (Coleoptera) in a wooded meadow and in the adjacent habitats on the Saaremaa Island, Estonia
}

\author{
Tõnu Talvi
}

Talvi, T. 1995: Carabid beetle assemblages (Coleoptera) in a wooded meadow and in the adjacent habitats on the Saaremaa Island, Estonia. - Entomol. Fennica 6:169-175.

Carabid beetles were sampled by using pitfall traps during one season in traditionally managed wooded meadow and in adjacent habitats (dry meadow, deciduous forest and spruce forest) on Saaremaa Island, Estonia. A total of 2356 carabids belonging to 35 species were caught. The number of species and species diversity were highest in the wooded meadow and lowest in the dry meadow. In the wooded meadow, the dominant species were Pterostichus melanarius (Illiger) and P. niger, (Schaller), which counted together for $49 \%$ of the total sample. The highest number of scarce species was found in the wooded meadow. Similarity of the carabid assemblages was highest between the two types of forests. The carabid assemblage in the wooded meadow was most similar to that of the deciduous forest; the values of similarity of wooded meadow versus spruce forest and wooded meadow versus dry meadow were only slightly lower. The results indicate that high biodiversity level of the wooded meadow can be maintained only through continuous traditional management.

Tõnu Talvi, Viidumäe Nature Reserve, Lümanda EE-3335 Saaremaa, Estonia

\section{Introduction}

Wooded calciferous meadows were formerly widespread in the countries around the Baltic Sea (Eichvald 1934, Haeggström 1983). The vegetation of a wooded meadow is a mosaic of two quite different plant communities, or groups of communities: small copses of (deciduous) trees and shrubs, and patches of open meadow, modified by human activity. The existence of wooded meadows depends on such activities as raking, gathering of leaf fodder from the trees, haymaking, grazing and clearing (Haeggström 1988). Thus, the regular mowing and clearing activity should be considered a desirable disturbance and as such a normal, continuous component of the environment.
Wooded meadow vegetation is heterogeneous and the flora is unusually rich in species, probably one of the richiest in temperate Europe (Kull \& Zobel 1991). Due to a marked decrease in the management and maintenance of wooded meadows during the recent decades, many of them have overgrown (Haeggström 1988, Truus et al. 1989).

Wooded meadows have been managed traditionally for centuries and the flora received attention, yet the fauna of the wooded meadows and community-level patterns are known inadequately or such studies are entirely lacking. The carabid beetles are one of the most extensively studied groups of terrestrial invertebrates (Thiele 1977, Den Boer 1986). This group of insects is a favourable study subject because of showing a great diversity of habitat preference, being a taxonomical unit of 
convenient size, and the beetles are easily sampled. At the community level, the analysis of the composition of carabid assemblages can provide useful insights into the impact of human activities in the ecosystems (Rushton et al. 1990). Despite much work on the habitat ecology of carabids in Europe (cf. Thiele 1977), most studies in Baltic Sea region have concentrated on natural habitats, such as boreal coniferous forest (e.g. Niemelä 1990b, Niemelä et al. 1992, Halme \& Niemelä 1993), archipelago habitats (e.g. Niemelä 1988), and on intensively cultivated land (e.g. Wallin 1985, Niemelä et al. 1987, Niemelä \& Halme 1992). Little information exists on the characteristics of the carabid beetles of traditionally managed seminatural habitats (Morris 1979, Niemelä 1990a).

In this study, I investigated the composition of the carabid beetle assemblages in a wooded meadow and in the adjacent habitats on the Saaremaa Island, Estonia. The habitats ranged from dry cultivated meadow to spruce forest. The study was focused on: (1) describing carabid beetle assemblages in different habitats, (2) comparing composition and diversity of observed assemblages and (3) discussing the results in the light of wooded meadow quality and management.

\section{Material and methods}

\subsection{Study area and habitats}

The study was conducted on the island of Saaremaa (area $2673 \mathrm{~km}^{2}$ ), located $15 \mathrm{~km} \mathrm{~W}$ from mainland Estonia in the Baltic Sea (ca. $58^{\circ} \mathrm{N}, 22^{\circ} \mathrm{E}$ ). Phytogeographically the region belongs to hemiboreal zone. Study area belongs to the Viidumäe Nature Reserve. Four sampling sites, chosen to be generally representative habitats of the area, were selected and the vegetation of the sites was described.

Meadow (ca. 6 ha) located at the side of the wooded meadow. This dry meadow is mowed annually, it was repeatedly fertilized and seeded earlier with a mixture of Dactylus glomerata, Medicago sativa and Trifolium spp. Other common plant species include Viscaria viscosa, Convolvulus arvensis, Anthoxanthum odoratum, Prunella vulgaris, Veronica chamaedrys, Festuca pratensis, Taraxacum officinale, Vicia cracca, Rumex acetosa, Achillea millefolium, Agrostis tenuis, Plantago media, Cerastium holosteoides.

Wooded meadow (ca. 3 ha) can be assigned to the dry calciferous wooded meadow of the Filipendula hexapetala - Sesleria coerulea subassociation (Laasimer 1965). Vegetation is a mosaic formed by small copses of mainly decidu- ous trees and shrubs, and patches of open meadow. The dominant tree species are Quercus robur, Betula pendula, Fraxinus excelsior and Picea abies. Other deciduous trees and shrubs are Sorbus aucuparia, S. intermedia, Populus tremula, Acer platanoides, Malus sylvestris, Lonicera xylosteum, Rhamnus cathartica, Frangula alnus, Crataegus monogyna, Corylus avellana, Viburnum opulus, Ribes alpinum. Herbs flora is rich in species, the dominant species being Rhinanthus serotinus, Potentilla erecta, Alchemilla. spp., Anemone nemorosa, Primula veris, Filipendula hexapetala, Anthoxanthum odoratum. The litter layer is thick and consists of leaves of herbs and deciduous trees. The investigated Mäepea wooded meadow has probably been cut for hay for more than 100 years, but only the study site, ca. 3 ha is still mown regularly. The management of the site is typical of wooded meadows on Saaremaa, including annual raking, mowing and periodical clearing. There are no records of grazing on the investigated wooded meadow during the last 40 years.

Deciduous forest stand (ca. 4 ha) sampling site lies about $50 \mathrm{~m}$ of the wooded meadow, partially as a division of the former wooded meadow and wooded pasture left unmanaged since ca. 1950. Dominant tree species are Quercus robur, Populus tremula, and Sorbus aucuparia, other trees and shrubs are Picea abies, Acer platanoides, Pinus sylvestris, Betula pendula, Tilia cordata, Fraxinus excelsior, Viburnum opulus, Lonicera xylosteum. The field layer is considerably poorer than in the wooded meadow. Convallaria majalis, Anemone nemorosa, Hepatica nobilis, Lathyrus vernus are dominants.

Spruce forest sampling site is located $100 \mathrm{~m}$ east of the wooded meadow. The forest is a mature stand with trees about 80-100 years old. Spruce, Picea abies, dominates the very closed canopy. Other tree species found are single specimens of Populus tremula, Betula pendula, Sorbus aucuparia. The dominanting plant species in the field layer are Vaccinum myrtillus and Maianthemum bifolium. The ground is mostly covered by a thick layer of spruce needle litter.

\subsection{Sampling procedure and calculations}

The carabids were collected using pitfall traps consisting of plastic cups (diameter $65 \mathrm{~mm}$, volume $170 \mathrm{ml}$ ), partly filled with water and ethylene glycol as preservative. Small covers $(10 \times 10 \mathrm{~cm})$ were placed above the traps to shelter them from rain. Fifteen traps were placed in $3 \times 5$ grids in each sampling site, 4-5 $\mathrm{m}$ from each other. To catch species active in the early summer and late summer the pitfall traps were in operation in two periods during the season: 26 May5 June, and 31 August-21 September, 1992. Trapping effort was 465 trap-days in every studied habitat type.

Shannon diversity index (H') was calculated in each habitat. The carabid assemblages from the various habitats were compared by using the Czekanowski-Sörensen index of percentage similarity. The structure of the carabid assem- 


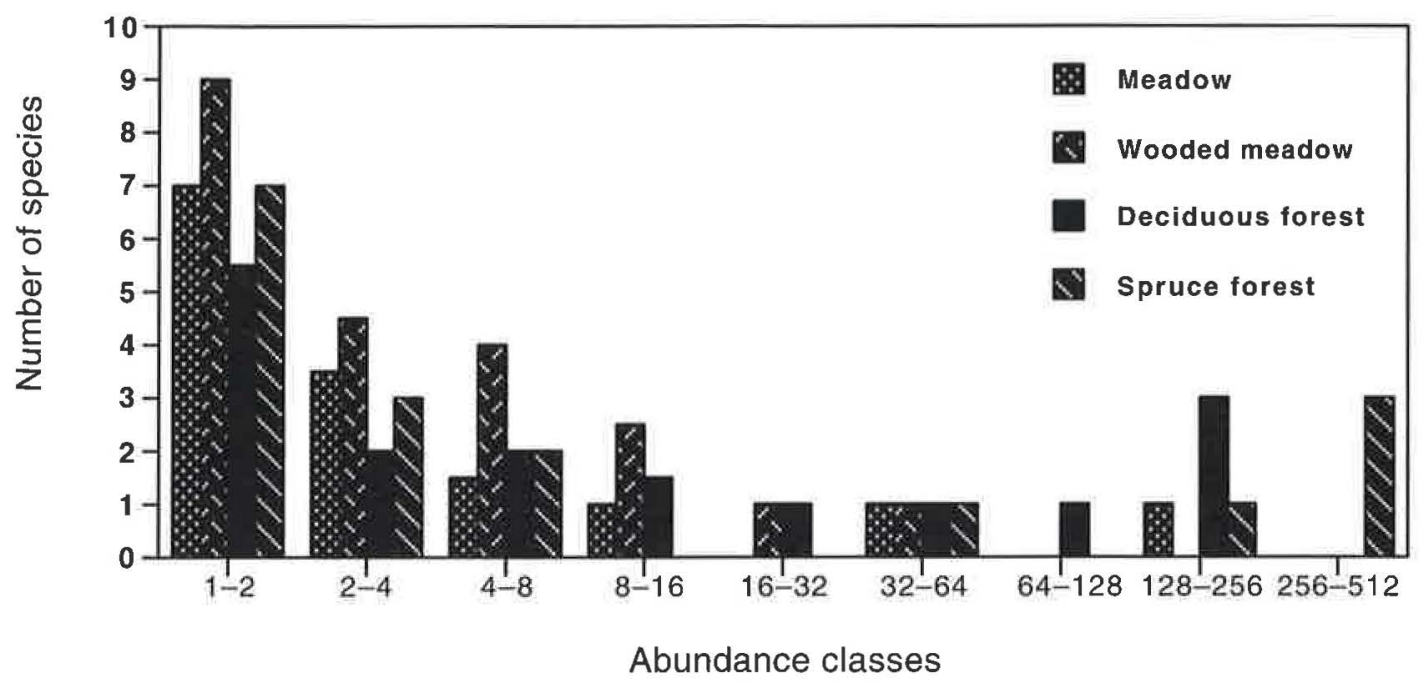

Fig. 1. Species-abundance distribution in the four habitat types investigated. The bars indicate the number of species in each of the abundance classes (Prestonian octaves).

blages in the different habitats was examined by plotting observed species abundance distributions using octaves (Preston 1962).

\section{Results}

\subsection{Distribution of species among habitats}

The total carabid catch from the four habitats consisted of 2356 individuals belonging to 35 species (Table 1). The most abundant species was Pterostichus melanarius (23\% of the total samples) and the next ones were Pterostichus oblongopunctatus ( $21 \%$ ) and Calathus micropterus (20\%). These species and two others, i.e. Pterostichus versicolor and Carabus hortensis, constituted $84 \%$ of the total number of carabids caught. According to literature (Haberman 1968, Lindroth 1985, 1986, Niemelä \& Halme 1992), the listed carabid species have been divided into four habitat preference classes:

1) Habitat generalists were abundant in all three woody habitats, but were less numerous in the open meadow.

2) Species of open habitats clearly favoured dry meadow and were absent from the forests. More than half of these species were found in wooded meadow in low numbers.

3) Deciduous forest species occurred in approxi- mately equal numbers in the three woody habitats, but were absent from the meadow.

4) Forest generalists were conspicuously numerous in the two forest habitats and were found in wooded meadow in low numbers. Most of these species are generalized forest species which occur over a wide range of different forest habitats.

About one third of the species (13) occured in only one studied habitat (Table 1). These species were scarce in total, only $1.1 \%$ of the whole catch. More of the unique species (with 1 individual) were collected in dry meadow and wooded meadow. All the dominant species were strictly associated with their preferred habitats. For instance, Pterostichus versicolor was the most abundant species in dry meadow, whereas in wooded meadow this species accounted only for $5.9 \%$, and in forests it was totally absent. Assemblages in the two forest types were dominated together by habitat generalist Pterostichus melanarius, and two forest generalists, Pterostichus oblongopunctatus and Calathus micropterus (ca. $27 \%, 2 \%$, and $25 \%$ of the total catch in those habitats, respectively). In the wooded meadow, the forest generalists accounted for significantly lower proportions; Pterostichus oblongopunctatus made up $3.7 \%$ and Calathus micropterus $2.2 \%$ of the total catch. Only the habitat generalist Pterostichus melanarius retained dominant posi- 
Table 1. The number of individuals of the carabid species caught in the four habitat types. Total catch, number of species, number of species found on one biotope only, and the value of Shannon diversity index $\left(\mathrm{H}^{\prime}\right)$ are given. Carabid species are classified into four habitat requirements according to Haberman (1968), Lindroth $(1985,1986)$ and Niemelä \& Halme (1992). The species are listed in the order of decreasinig sample size within each habitat type.

\begin{tabular}{|c|c|c|c|c|c|}
\hline Total & $\begin{array}{r}\text { Dry } \\
\text { meadow }\end{array}$ & $\begin{array}{l}\text { Wooded } \\
\text { meadow }\end{array}$ & $\begin{array}{r}\text { Deciduous } \\
\text { forest }\end{array}$ & $\begin{array}{r}\text { Spruce } \\
\text { forest }\end{array}$ & \\
\hline \multicolumn{6}{|l|}{ Habitat generalists: } \\
\hline Pterostichus melanarius (Illiger) & 3 & 39 & 236 & 275 & 553 \\
\hline Trechus secalis (Paykull) & 0 & 0 & 69 & 23 & 92 \\
\hline Pterostichus niger (Schaller) & 10 & 27 & 12 & 36 & 85 \\
\hline Carabus nemoralis Müller & 0 & 0 & 23 & 0 & 23 \\
\hline Harpalus latus (Linnaeus) & 0 & 7 & 1 & 1 & 9 \\
\hline Amara familiaris (Duftschmid) & 4 & 2 & 3 & 0 & 9 \\
\hline Leistus ferrugineus (Linnaeus) & 0 & 4 & 1 & 1 & 6 \\
\hline Amara communis (Panzer) & 5 & 0 & 0 & 0 & 5 \\
\hline Notiophilus palustris (Duftschmidt) & 0 & 3 & 0 & 0 & 3 \\
\hline Pterostichus nigrita (Paykull) & 0 & 1 & 0 & 1 & 2 \\
\hline Amara lunicollis Schiödte & 1 & 1 & 0 & 0 & 2 \\
\hline Carabus granulatus Linnaeus & 0 & 1 & 0 & 0 & 1 \\
\hline Harpalus tardus (Panzer) & 0 & 10 & 0 & 1 & 11 \\
\hline \multicolumn{6}{|l|}{ Species of open habitats: } \\
\hline Pterostichus versicolor (Sturm) & 233 & 8 & 0 & 0 & 241 \\
\hline Calathus fuscipes (Goeze) & 53 & 6 & 0 & 0 & 59 \\
\hline Amara aenea (Degeer) & 3 & 2 & 0 & 0 & 5 \\
\hline Amara nitida Sturm & 0 & 3 & 0 & 0 & 3 \\
\hline Amara similata (Gyllenhal) & 1 & 1 & 1 & 0 & 3 \\
\hline Microlestes minutulus (Goeze) & 1 & 1 & 0 & 0 & 2 \\
\hline Clivina fossor (Linnaeus) & 1 & 0 & 0 & 0 & 1 \\
\hline Dyschirius globosus (Herbst) & 1 & 0 & 0 & 0 & 1 \\
\hline Pterostichus cupreus (Linnaeus) & 1 & 0 & 0 & 0 & 1 \\
\hline Calathus melanocephalus (Linnaeus) & 1 & 0 & 0 & 0 & 1 \\
\hline \multicolumn{6}{|l|}{ Deciduous forest species: } \\
\hline Pterostichus strenuus (Panzer) & 0 & 9 & 5 & 1 & 15 \\
\hline Badister lacertosus Sturm & 0 & 1 & 8 & 1 & 10 \\
\hline Platynus assimilis (Paykull) & 0 & 0 & 0 & 5 & 5 \\
\hline Leistus terminatus (Hellwig) & 0 & 0 & 1 & 0 & 1 \\
\hline \multicolumn{6}{|l|}{ Forest generalists: } \\
\hline Pterostichus oblongopunctatus (Fabricius & us) & 5 & 159 & 334 & 498 \\
\hline Calathus micropterus (Duftschmid) & 0 & 3 & 139 & 340 & 482 \\
\hline Carabus hortensis Linnaeus & 3 & 10 & 34 & 169 & 216 \\
\hline Notiophilus biguttatus (Fabricius) & 0 & 0 & 4 & 4 & 8 \\
\hline Cychrus caraboides (Linnaeus) & 0 & 1 & 2 & 4 & 7 \\
\hline Carabus coriaceus Linnaeus & 0 & 0 & 0 & 3 & 3 \\
\hline Harpalus quadripunctatus Dejean & 0 & 0 & 1 & 1 & 2 \\
\hline Amara brunnea (Gyllenhal) & 0 & 0 & 0 & 1 & 1 \\
\hline Total catch & 321 & 136 & 699 & 1200 & 2356 \\
\hline Number of species & 15 & 22 & 17 & 17 & 35 \\
\hline Species found on one biotope only & 5 & 4 & 1 & 3 & \\
\hline$H^{\prime}$ & 1.01 & 2.40 & 1.79 & 1.62 & \\
\hline
\end{tabular}


tion (29\%). The secondmost abundant species in the wooded meadow was Pterostichus niger, with about $20 \%$ of the sample.

\subsection{Species-abundance distribution}

The abundance of individual species varied considerably among the habitats. Sample size was higher in the samples from the spruce forest and the deciduous forest. The species-abundance distribution was more similar in meadow-wooded and meadow habitat types and in the two forest types (Fig. 1). In the latter two habitats the abundant species formed a distinct group. In meadow and particularly in the wooded meadow, speciesabundance distribution became more similar to normal pattern, as the proportion of scarce species (1-2 individuals) was high. The highest number of scarce species was found in wooded meadow.

\subsection{Species richness, diversity and similarity among habitats}

The species richness and Shannon diversity index were highest in the wooded meadow and lowest in the dry meadow (Table 1 ). The diversity values were rather similar in the two forest habitats and expectedly, these habitats had the most similar carabid assemblages (Table 2). The assemblage of the wooded meadow indicated the highest similarity to that of the deciduous forest habitat. Only slightly smaller values were found between wooded meadow and spruce forest, and wooded meadowdry meadow habitat assemblages. The assemblages of the woody habitats showed higher level of similarity between each other when compared to the meadow assemblage. Thus, the wooded meadow formed an intermediate habitat between the meadow and the forested habitats in terms of carabid assemblages.

\section{Discussion}

This study demonstrated habitat associations of carabid beetles with broad habitat types, such as "forest" versus "meadow". However, some abundant species showed a slightly different distribution pattern than that shown by previous faunistic and biogeographic studies. Pterostichus niger has often

Table 2. Values for the Czekanowski-Sörensen index of percentage similarity among the four habitat types.

\begin{tabular}{llcc}
\hline & $\begin{array}{c}\text { Dry } \\
\text { meadow }\end{array}$ & $\begin{array}{c}\text { Decidous } \\
\text { forest }\end{array}$ & $\begin{array}{c}\text { Spruce } \\
\text { forest }\end{array}$ \\
\hline Wooded meadow & 54.1 & 61.5 & 56.4 \\
Dry meadow & & 31.3 & 18.8 \\
Deciduous forest & & & 76.5 \\
\hline
\end{tabular}

Table 3. Catch-number $(\mathrm{N})$ and proportion $(\mathrm{P}, \%)$ of the eight dominant species caught in wooded meadow on the island of Nåtö, Åland Islands (Niemelä 1990) and island of Saaremaa (present study). As the sampling efforts were not identical on the two sites, the catch numbers have been modified to individuals per 1000 trapping days. The species are arranged by their total proportion in both study areas together. Habitat requirement types: Gen = habitat generalists, For = forest generalists, and Dec = deciduous forest species.

\begin{tabular}{llrrrr}
\hline & Habitat & \multicolumn{2}{c}{ Nåtö } & \multicolumn{2}{c}{ Saaremaa } \\
\hline Pterostichus melanarius & Gen & 176.6 & 49.4 & 83.9 & 28.7 \\
Patrobus atrorufus & Gen & 79.7 & 22.3 & - & - \\
Pterostichus niger & Gen & 2.7 & 0.8 & 58.1 & 19.9 \\
Pterostichus oblongopunctatus & Gen & 24.7 & 6.9 & 10.8 & 3.7 \\
Pterostichus strenuus & Dec & 13.7 & 3.8 & 19.4 & 6.6 \\
Carabus hortensis & For & 1.4 & 0.4 & 21.5 & 7.4 \\
Calathus micropterus & For & 10.3 & 2.9 & 6.5 & 2.2 \\
Trechus secalis & Gen & 8.9 & 2.5 & - & - \\
\hline
\end{tabular}


been characterized as a forest generalist, occurring only scarcerly in open habitats (Haberman 1968, Lindroth 1985, 1986). My records support the observations of Wallin (1985) and Niemelä \& Halme (1992), who also found the species being abundant on open habitats. Pterostichus strenuus has been traditionally classified as a stenotopic deciduous forest species (Lindroth 1986). In my study, however, $60 \%$ of the individuals caught were from the wooded meadow, but the species was absent in dry meadow catches. Niemelä \& Halme (1992) found the species to be abundant in the Åland Islands also in different open habitats.

It is likely that some carabid species are dependent on more than one type of habitat at different stages of their life histories. Such dependence may be of special importance to species which require particular conditions for successful overwintering or reproduction (Wallin 1985). In wooded meadow, this concept may help to explain simultaneous occurrence of the species with different habitat requirements.

It is worth noting that the relative abundance of many carabid species found in the wooded meadow in Saaremaa is similar to that reported by Niemelä (1990a) in a wooded meadow in the Åland Islands. The eight most abundant species from both studied wooded meadows are listed in Table 3 . Two habitat requirement types were noticeably present among the wooded meadow dominants: the habitat generalists and the forest generalists. They formed the basis of the wooded meadow carabid assemblage on both areas studied. The group of dominant species was complemented by the presence of the light deciduous forest specialist Pterostichus strenuus. In Saaremaa, some open habitat species (Pterostichus versicolor, Calathus fuscipes) were relatively abundant also in the wooded meadow.

The general view that the human-modified habitats support the most diverse, and the forests the least diverse carabid assemblages (Thiele 1977, Spence 1990, Niemelä 1990a, Niemelä et al. 1992, Halme \& Niemelä 1993), is supported by the present study. Furthermore, the number of species not found elsewhere was higher in the meadow and the wooded meadow. The pattern of higher numbers of rare species in open habitats in comparison to forests has been shown also by other studies (Niemelä et al. 1987, Niemelä \& Halme 1992, Niemelä et al. 1992).
The high species richness in the mosaic, semiopen habitat is attributable to several factors. Species of open habitats, dominant in adjacent meadows, may invade the wooded meadows, and at the same time, many forest species still persist there. The decrease in overall carabid abundance in the wooded meadow is interpreted mainly as resulting from the dwindling population size of the more specialized species groups. Thus, species favouring open habitats and the forest generalists occurred in high numbers in their respective habitats, but did not dominate in abundance in the wooded meadow assemblage. Only the habitat generalists, as a result of their broader habitat requirements, remained on their usual relative abundance level (cf. Thiele 1977, Niemelä \& Halme 1992).

The important environmental factors determing the composition of the carabid assemblages are the vegetation structure, moisture, substrate porosity and management activity (Thiele 1977, Morris \& Rispin 1987, Luff et al. 1989, Rushton et al. 1990). As most carabid species are generalist predators (Hengeveld 1980), they are not strictly associated with food plants, but with the local habitat heterogeneity, which supports potential food items and creates suitable environments for breeding and hibernation (cf. Liebherr \& Mahon 1979). Thus, the wooded meadow carabid beetle assemblage can be classified as a transient type between the two " $\mathrm{ex}$ treme" types, i.e. meadow and forests.

To conclude, the preliminary data provide a qualitative and quantitative characterization of the carabid assemblages in a wooded meadow and adjacent habitats. The results show that the traditional management of wooded meadows affects the composition of their fauna. The carabid assemblage in these mosaic habitats was considerably more diversified than that of the adjacent habitats. It is evident that the overgrowth of wooded meadows and change into a forest causes a decline in the carabid fauna. Both natural and semi-natural communities should be maintained side by side in the nature reserves in order to support diverse fauna and flora. The conservation activity of wooded meadows should be widened beyond their floristic contents.

Acknowledgements. I wish to thank Dr. Antti Pekkarinen, Dr. Kauri Mikkola, and an anonymous referee for their valuable comments on the manuscript. The participation in the XXIII Nordic Entomological Meeting was supported by the Viro Foundation (= Viro Säätiö). 


\section{References}

Den Boer, P. J. 1986: Carabids as objects of study, pp. 539 551. - In Den Boer, P. J., Luff, M. L., Mossakowski, D. and Weber, F. (eds.): Carabid Beetles, Their Adaptations and Dynamics. Fischer Verlag, 551 pp.

Eichvald, K. 1934: Taimkate [Vegetation], pp. 40-75. -- In Luha, A., Blumfeld, E., Tammekann, A. (eds.): Eesti. VI. Saaremaa, 857 pp.

Haberman, H. 1968: Die Laufkäfer Estlands. — Tallinn, 598 pp. (in Estonian, German summary).

Haeggström, C.-A. 1983: Vegetation and soil of the wooded meadows in Nåtö, Åland. — Acta Bot. Fenn. 120: 1-66.

- 1988: Protection of wooded meadows in Åland problems, methods and perspectives. - Oulanka Reports 8: 88-95.

Halme, E. \& Niemelä, J. 1993: Carabid beetles in fragments of coniferous forest. - Ann. Zool. Fennici 30: 17-30.

Hengeveld, R. 1980: Qualitative and quantitative aspects of the food of ground beetles (Coleoptera, Carabidae): A review. - Neth. J. Zool. 30: 555-563.

Kull, K. \& Zobel, M. 1991: High species richness in an Estonian wooded meadow. - J. Veg. Sci. 2: 711-714.

Laasimer, L. 1965: Vegetation of the Estonian S. S. R. Tallinn, 397 pp. (in Estonian, English summary).

Liebherr, J. \& Mahon, J. 1979: The carabid fauna of the upland forest in Michigan: survey and analysis. The Coleopts. Bull. 33: 183-197.

Lindroth, C. H. 1985: The Carabidae (Coleoptera) of Fennoscandia and Denmark. - Fauna Entomol. Scand. 15(1): 1-225.

- 1986: The Carabidae (Coleoptera) of Fennoscandia and Denmark. - Fauna Entomol. Scand. 15(2): 233-497.

Luff, M. L., Eyre, M. D. \& Rushton, S. P. 1989: Classification and ordination of habitats of ground beetles (Coleoptera, Carabidae) in north-east England. - J. Biogeogr. 16: 121-130.

Morris, M. G. 1979: Grassland management and invertebrate animals - a selective review. - Sci. Proc. R. Dublin Soc. (A) 6: 129-139.

Morris, M. G. \& Rispin, W. E. 1987: Abundance and diversity of the coleopterous fauna of a calcareous grassland under different cutting régimes. - J. Appl. Ecol. 24: 451-465.

Niemelä, J. 1988: Carabid beetles in shore habitats on the Åland Islands, SW Finland: the effect of habitat avail- ability and species characteristics. - Acta Oecol./ Oecol. Gener. 9: 379-395.

- 1990a: Effect of changes in the habitat on carabid assemblages in a wooded meadow on the Åland Islands. - Notulae Entomol. 69: 169-174.

- 1990b: Spatial distribution of carabid beetles in the southern Finnish taiga: the question of scale, pp. 143 155. - In Stork, N. E. (ed.): The Role of Ground Beetles in Ecological and Environmental Studies. Intecept, Andover, $424 \mathrm{pp}$.

Niemelä, J., Haila, Y. \& Halme, E. 1987: Carabid assemblages in southern Finland, a forest - field comparison. - Acta Phytopath. Entom. Hung. 22: 417-424.

Niemelä, J., Haila, Y., Halme, E., Pajunen, T. \& Punttila, P. 1992: Small-scale heterogeneity in the spatial distribution of carabid beetles in the southern Finnish taiga. J. Biogeogr. 19: 173-181.

Niemelä, J. \& Halme, E. 1992: Habitat associations of carabid beetles in fields and forests in the Åland Islands, SW Finland. - Ecography 15: 3-11.

Niemelä, J., Spence, J. R. D. \& Spence, D. H. 1992: Habitat associations and seasonal activity of ground-beetles (Coleoptera, Carabidae) in central Alberta. - Canadian Entomol. 124: 521-540.

Preston, F. W. 1962: The canonical distribution of commonness and rarity. Part I and II. - Ecology 43: 185215 and $410-432$.

Rushton, S. P., Eyre, M. D. \& Luff, M. L. 1990: The effect of scrub management on the ground beetles of oolitic limestone grassland at Castor Hanglands National Nature Reserve, Cambridgeshire, UK. - Biol. Conserv. 51: 97-111.

Spence, J. R. 1990: Success of European carabid species in western Canada: preadaptation for synanthropy? Pp. 129 141. - In Stork, N. E. (ed.): The Role of Ground Beetles in Ecological and Environmental Studies. Intercept, Andover, 424 pp.

Thiele, H.-U. 1977: Carabid Beetles in their Environments. - Springer Verlag, Berlin, $369 \mathrm{pp}$.

Truus, L., Ksenofontova, T. \& Kull, K. 1989: Decay of Estonia's richest plant communities. - Eesti Loodus 6: 354-361 (in Estonian, English summary).

Wallin, H. 1985: Spatial and temporal distribution of some abundant carabid beetles (Coleoptera: Carabidae) in cereal fields and adjacent habitats. - Pedobiologia 28: $19-34$. 